MAJA BŁASZAK

\title{
BUDŻET OBYWATELSKI W POLSCE I DYLEMATY Z NIM ZWIĄZANE
}

\section{WPROWADZENIE}

„Demokracja jest wtedy, gdy dwa wilki i owca decyduja, co zjeść. Wolność jest wtedy, gdy uzbrojona po zęby owca może bronić się przed demokratycznie podjętą decyzją". Te słowa Benjamina Franklina są dobra metaforą budżetu obywatelskiego. $\mathrm{Z}$ założenia jest to instrument wolności, ale w praktyce demokratyczne narzędzie, w którym mieszkańcy jako owca i władze samorządowe jako wilki próbują decydować o tym, jak zaspokajać potrzeby mieszkańców „owiec”. Co zrobić, aby budżet obywatelski stał się synonimem wolności, a nie tylko demokracji? Jakie wątpliwości i bariery stoją na przeszkodzie?

Celem artykułu jest próba zdiagnozowania źródeł dylematów funkcjonowania budżetu obywatelskiego w Polsce. Autorka prezentuje w nim model budżetu obywatelskiego jako dość nowe i ciagle rozwijające się narzędzie partycypacji mieszkańców w zarządzaniu miastem. Poza tym stawia pytania:

- Czy zmienne uwarunkowania finansowe, prawne, społeczne i organizacyjne wspieraja, czy hamują rozwój partycypacji obywatelskiej?

- Czy można wskazać kierunki zmian, jakie powinny następować, aby budżet partycypacyjny był jak najwłaściwiej i najefektywniej wykorzystywanym narzędziem wspierania rozwoju lokalnego?

Podstawa metodologiczną artykułu jest analiza źródeł wtórnych, w tym literatury polskiej i anglojęzycznej, a także analiza przypadków.

\section{PARTYCYPACJA OBYWATELI I BUDŻET OBYWATELSKI - DEFINICJE PROBLEMU}

Partycypacja jest jednym z podstawowych elementów obywatelskości. Określa więc prawa obywateli do pełnego i równego uczestniczenia w sprawowaniu władzy w mieście lub innych jednostkach samorządowych. Gdybyśmy spojrzeli na partycypację społeczną w tradycyjny sposób, określilibyśmy ja jako „udział mieszkańców w kreowaniu i realizacji polityki, co zarezerwowane było dotąd do wyłącznej kompetencji władzy samorządowej i admi- 
nistracji”'. Partycypacja dotyczy udziału mieszkańców, którzy oddziałuja przez swoją aktywność na decyzje i działania samorządu lokalnego. Decyzje te moga być podejmowane przez podmioty cechujace się demokratyczna legitymizacja, a więc takie osoby, które sprawują władzę wykonawczą (np. prezydent, wójt, radni) ${ }^{2}$.

Gdybyśmy jednak spojrzeli na partycypację społeczną w nowoczesny sposób, należałoby określić ją nie tylko jako udział różnych grup społeczności lokalnych w tworzeniu polityk publicznych (m.in. budowaniu strategii rozwoju), lecz także widzieć ją jako ich udział w podejmowaniu decyzji i realizacji zadań sformułowanych wspólnie z władzą samorządową tych polityk ${ }^{3}$.

$\mathrm{W}$ teorii partycypacji realny wymiar wpływu obywatela na podejmowane decyzje jest czynnikiem kluczowym ${ }^{4}$. Partycypacja obywatelska jest jednym z trzech elementów obywatelskości, obok praw indywidualnych jednostki oraz przynależności narodowej. Z uwagi na wielowątkowość procesów decyzyjnych włączanie w nie obywateli, niestety, nie jest oczywiste. Dylematów związanych z włączaniem obywateli w proces współzarządzania jest wiele. Partycypacja obywatelska jest celem samym w sobie, ale również metodą dążenia do zrównoważonego rozwoju.

Jednym z bardziej popularnych ostatnio w Polsce instrumentów partycypacji społecznej $\mathrm{w}$ zarządzaniu miastem jest budżet partycypacyjny (obywatelski). W polskich miastach od 2012 r. społeczności lokalne mogą zgłaszać projekty, które mogłyby być realizowane w ramach funduszy miasta. Budżet partycypacyjny określany jest jako „proces decyzyjny, w ramach którego mieszkańcy współtworzą budżet danego miasta, współdecydując tym samym

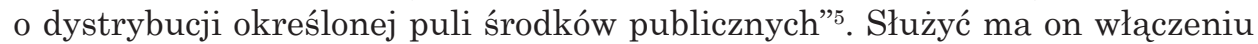
mieszkańców w współtworzenie budżetu miasta, z którym to mieście mieszkają albo pracuja. Zakłada się, że projekty realizowane w ramach budżetu partycypacyjnego sa zadaniami z katalogu zadań własnych. W praktyce władze samorządowe wskazują odgórnie obszar, w którym projekty mogą być zgłaszane, a potem realizowane ${ }^{6}$.

Definicja zaproponowana przez Kłębowskiego zakłada pewne warunki, które jego zdaniem muszą być spełnione, aby realizacja budżetu obywatelskiego mogła nastapić. Tymi warunkami sa:

- dialog władz samorzą dowych z mieszkańcami (należy też zwrócić uwagę, że dyskusje mieszkańców moga, a wręcz powinny, zachodzić w układzie mieszkańcy-mieszkańcy);

- wydzielenie wyraźnie ustalonej puli środków przeznaczonych na realizację projektów wybranych w ramach budżetu obywatelskiego;

\footnotetext{
1 Boryczka (2015): 42-43.

2 Swianiewicz, Klimska (2004): 35-42.

3 Boryczka (2015): 42-43.

4 Poczykowska (2013): 52.

5 Kębłowski (2013): 8.

${ }^{6}$ Boryczka (2015): 61-82.
} 
- gwarancja wiążącego charakteru decyzji podjętych przez mieszkańców w ramach podejmowanych decyzji (np. głosowania);

- dążenie do powtarzalności, długofalowości, a więc organizowanie budżetu obywatelskiego rokrocznie, aby dać możliwość kontynuowania rozpoczętych w ramach projektów działań i ich rozwój ${ }^{7}$.

Myśląc o tym, jaki jest charakter i cel realizowanych budżetów obywatelskich, warunki te wydają się oczywiste i proste do spełnienia. Wykorzystywanie aktywności mieszkańców w wielu aspektach współzarządzania miastem rodzi jednak wiele dylematów i wątpliwości.

\section{DYLEMATY REALIZACJI BUDŻETU OBYWATELSKIEGO W POLSCE}

Z perspektywy trendów ogólnoświatowych, nastawionych na zrównoważony rozwój, realizowanie budżetów obywatelskich wydaje się istotne. Ostatecznie mają one wpływ na zrównoważony rozwój miast. Jeden z 17 Celów Zrównoważonego Rozwoju (nr 11) wskazanych w Agendzie 2030 odnosi się do budowy bezpiecznych, sprzyjających włączeniu społecznemu oraz zrównoważonych miast i osiedli ludzkich ${ }^{8}$. W związku z tym wydaje się, że kierunek działań wdrażany w Polsce od kilku lat i zwiększający poziom partycypacji obywateli w zarządzaniu miastem jest jak najbardziej właściwy. Można zatem powiedzieć, że budżet obywatelski jest bardzo wskazanym narzędziem partycypacji.

Z dokumentów wynika, że w ramach budżetu obywatelskiego powinny być realizowane zadania własne samorządu. Zadania te mogą mieć charakter obligatoryjny albo fakultatywny. Zakres budżetów, forma ich organizacji, a także wymiar społeczny i polityczny w różnych miastach wyglądają nieco inaczej, mimo iż z założenia wyglądać powinny podobnie.

Wskazane jest, aby efektywność wydatkowania środków publicznych w ramach budżetu obywatelskiego analizować w kontekście poziomu zaspokojenia potrzeb, który można mierzyć liczbą głosów oddanych przez mieszkańców w stosunku do wydatków poniesionych na zadania. Natomiast skuteczność tego wydatkowania powinna wiąać się ze stopniem realizacji wyznaczonych zadań $^{9}$. Tak jak w teorii decyzji - racjonalność czy efektywność decyzji można próbować określać przed jej podjęciem, natomiast jej skuteczność można ocenić dopiero po jej podjęciu, analizując efekty, jakie wywarła ${ }^{10}$.

Różne podejścia do realizacji budżetu obywatelskiego generują jednak szereg dylematów i wątpliwości związanych z efektywnością i skutecznością tego instrumentu. Z uwagi na źródła pojawiających się wątpliwości można podzielić je na pewne grupy.

${ }^{7}$ Kębłowski (2014): 8.

8 Organizacja Narodów Zjednoczonych, Agenda na Rzecz Zrównoważonego Rozwoju 2030, 25 września 2015 r., <http://sustainabledevelopment.un.org/post/2015/transformingourworld>.

${ }^{9}$ Gońda (2017): 153-169.

${ }^{10}$ Peterson (2010): 4-5. 


\section{Schemat 1}

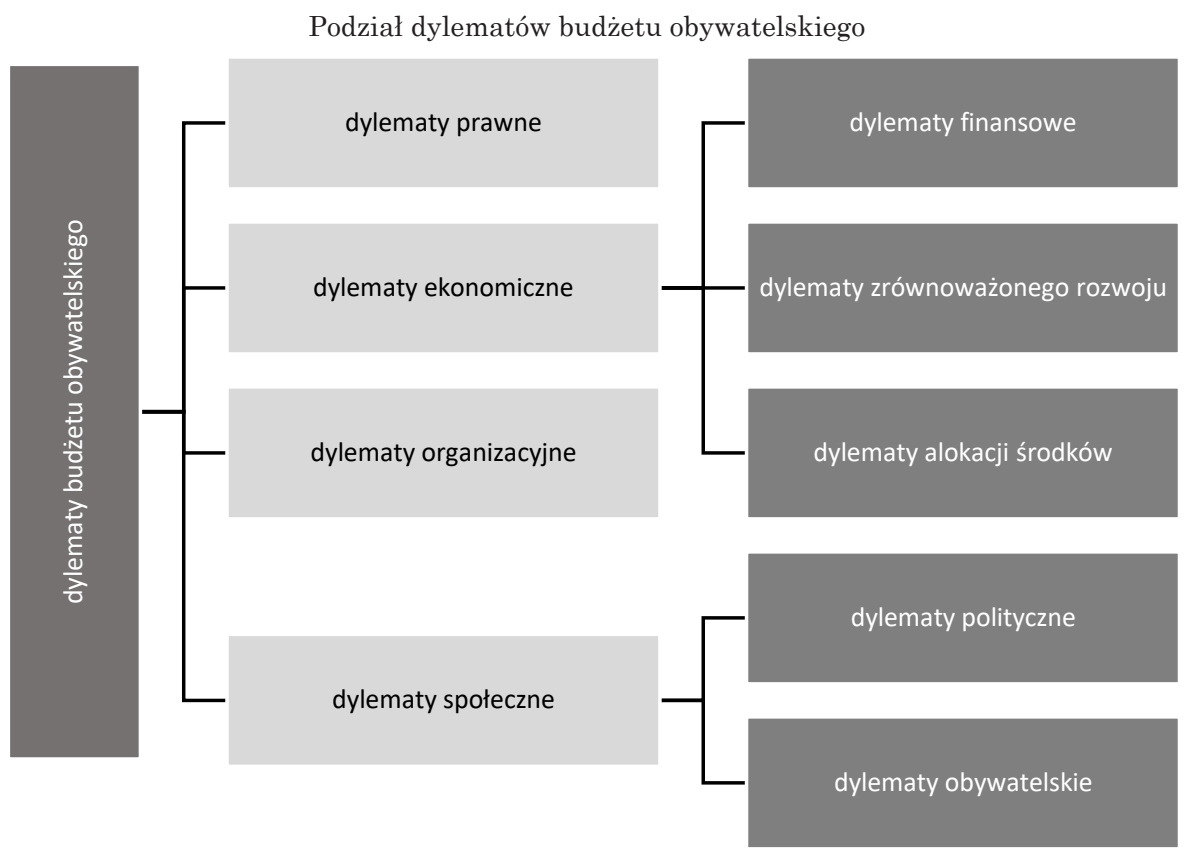

Źródło: opracowanie własne.

Aspekt finansowy i prawny w tym obszarze wydają się szczególnie istotne, ale dodatkowo trzeba rozstrzygać wątpliwości o charakterze społecznym i organizacyjnym. Wszystkie wymienione wattpliwości stanowią znaczne ograniczenia w rozwoju budżetu obywatelskiego w Polsce, co więcej, dość często ich zakresy się przenikaja.

\section{Dylematy prawne}

Pierwsza z wątpliwości wynika z polskiego ustawodawstwa i zapisów z niego wypływających. Ustawa z 11 stycznia 2018 r. o zmianie niektórych ustaw w celu zwiększenia udziału obywateli w procesie wybierania, funkcjonowania i kontrolowania niektórych organów publicznych ${ }^{11}$, mająca na celu nowelizację kodeksu wyborczego, wprowadziła kilka zmian w zakresie funkcjonowania samorządu terytorialnego. Zmiana ta nakazała miastom na prawach powiatu włączenie do swojej polityki budżet obywatelski jako narzędzie obligatoryjne. Wskazana ustawa uregulowała przede wszystkim dwie instytucje partycypacji, a więc inicjatywę obywatelską i budżet obywatelski. Oba rozwiązania były

${ }^{11}$ Ustawa z 11 stycznia 2018 r. o zmianie niektórych ustaw w celu zwiększenia udziału obywateli w procesie wybierania, funkcjonowania i kontrolowania niektórych organów publicznych, Dz. U. 2018, poz. 140 (dalej jako: u.z.u.o.). 
wcześniej obecne w prawie samorządowym, jednakże nie były objęte zapisami ustawowymi. Celowość wprowadzenia tego typu rozwiąań do ustaw ustrojowych można uznać za dyskusyjną ${ }^{12}$. Takie rozwiązanie jest szczególnie wątpliwe, zważywszy, że centralne regulowanie budżetu obywatelskiego w państwach demokratycznych jest wyjątkowo rzadkie ${ }^{13}$.

$\mathrm{Z}$ jednej strony brak takich zapisów powodował problemy praktyczne. Przykładem mogą być decyzje sądów administracyjnych, które brakiem tych zapisów motywowały brak możliwości podejmowania inicjatywy uchwałodawczej przez mieszkańców. Z drugiej strony obecna praktyka działania sądów administracyjnych nie może być uznana za blokujaccą wykorzystywanie tych mechanizmów partycypacyjnych, gdyż powszechnie akceptuje się prawna możliwość ich wprowadzenia. Poza tym wdrożenie rozwiązań ustawowych wpływa na ograniczenie swobody samorządów w kształtowaniu takich narzędzi i dopasowywaniu ich do specyfiki danej jednostki. Ingeruje to również w samodzielność podejmowania decyzji przez samorząd terytorialny. Wydaje się więc, że przyjęte rozwiązania powinny jedynie dawać możliwość wprowadzenia mechanizmów partycypacyjnych i pozostawiać jednostkom samorzadowym możliwość dopasowania ich w sposób odpowiadający potrzebom lokalnym $^{14}$. Porządkowy charakter regulacji można dostrzec zarówno w zakresie budżetu obywatelskiego, jak i inicjatywy uchwałodawczej mieszkańców. Nie zmienia to faktu, że niekiedy ramy te mogą być zbyt sztywne i komplikuja sprawną realizację zadań przez samorząd.

Co więcej, pojawia się pytanie, dlaczego tylko miasta na prawach powiatu zostały zobligowane do włączania budżetów obywatelskich, a nie wszystkie miejscowości mające prawa miejskie albo wszystkie miejscowości powyżej pewnej liczby mieszkańców. Oczywiście miasta na prawach powiatu różnia się od pozostałych koniecznością realizowania odpowiednich zadań, narzuconych im odgórnie z uwagi na zadania administracyjne, jakie w powiecie muszą być realizowane. Nałożenie tego obowiązku tylko na miasta powiatowe budzi wątpliwości, gdyż miasta, które nie mają takich praw, mogą być większe, a nie zostały zobowiązane do wdrażania tego instrumentu. Przykładem moga być Czechowice-Dziedzice, które wchodzą w skład powiatu bielskiego w województwie śląskim. Jest to średnie miasto liczące ponad 35 tysięcy mieszkańców. Za to Szamotuły jako miasto na prawach powiatu w województwie wielkopolskim liczą niespełna 20 tysięcy mieszkańców.

Wspomniana nowelizacja z 2018 r. podtrzymała zapis, że budżet obywatelski jest traktowany jako forma konsultacji społecznych, które mogą być przeprowadzane z mieszkańcami jednostki samorządu terytorialnego. Co ciekawe, wyniki konsultacji nie są wiążące dla organów samorządowych, a tym samym zadania wyłonione przez mieszkańców w ramach budżetu obywatelskiego powinny być uwzględnione przez władze samorządowe. Nowe zapisy stanowia, że decyzje mieszkańców w zakresie wyboru projektów mają mieć charakter

\footnotetext{
12 Bułajewski (2013): 95.

13 Rytel-Warzocha (2013): 68.

14 Glejt (2015): 376.
} 
wiążący. Zapisy te są jednak niespójne. Obecne zapisy wprowadzają zasadę związania wynikami głosowania w ramach budżetu obywatelskiego ${ }^{15}$. Co do wiążącego charakteru podejmowanych przez mieszkańców decyzji ustawa przewiduje dokonywanie modyfikacji wybranych projektów. W art. 5 u.z.u.o. wspomnianej ustawy „rada gminy w toku prac nad projektem uchwały budżetowej nie może usuwać lub zmieniać w stopniu istotnym zadań wybranych w ramach budżetu obywatelskiego". Nie zabrania to jednak dokonywania zmian $\mathrm{w}$ projektach o charakterze mniej istotnym. Brak dokładności w tym zapisie w praktyce może oznaczać dokonywanie zmian w projektach, uzasadnianych ich znikomym znaczeniem, a tym samym zmienić sens i zakres tych projektów ${ }^{16}$.

Jeszcze innym czynnikiem prawnym są regulacje dotyczące procedury budżetowej. Zgodnie z nimi jedynymi organami majacymi kompetencje w zakresie opracowania i przyjęcia budżetu danej jednostki samorządu terytorialnego są organ wykonawczy i organ stanowiący. Organ wykonawczy przygotowuje projekt uchwały budżetowej, natomiast organ stanowiący dokonuje jego autoryzacji ${ }^{17}$. Decydowanie przez mieszkańców o kierunkach wydatków w ramach budżetu obywatelskiego nie ma więc wyraźnych podstaw prawnych. Można stwierdzić, że budżet obywatelski jest swoista „umową dżentelmeńską” między organem wykonawczym, organem stanowiącym i mieszkańcami ${ }^{18}$.

Zdarza się również, że wątpliwości prawne dotyczą procedur zgłaszania i wybierania projektów. Przykładem może być budżet obywatelski miasta Kraśnik w 2014 r. ${ }^{19}$ Problem polegał na niewłaściwie prowadzonym nadzorze nad sama procedura zgłaszania i wskazywania zwycięskich projektów w ramach budżetu obywatelskiego. Mimo - wydaje się - bezspornych uwarunkowań prawnych wynikających z ustawy z 8 marca 1990 r. o samorządzie (art. 7), do głosowania mieszkańców dopuszczono projekt przebudowy dachu kościoła. Finansowanie celów kultu religijnego (w tym budowy, przebudowy budynków kościelnych) nie mieści się w zakresie zadań własnych miasta. Niemniej projekt ten zyskał największą liczbę głosów i wpisano go do budżetu miasta. Władze miasta (z burmistrzem i radą miasta na czele) powinny zdawać sobie sprawę, że tego typu inwestycja nie może być finansowana ze środków budżetu miasta, a jednak zaakceptowały wybór mieszkańców. Kontrola regionalnej izby obrachunkowej wykazała, że taki projekt nie może być realizowany w ramach budżetu obywatelskiego i zmusiła władze Kraśnika do zmiany projektu. Ostatecznie zrealizowany został projekt, który również wskazali mieszkańcy, ale otrzymał on mniejszą liczbę głosów. Sytuacja spowodowała wiele napięć między władzami miasta a mieszkańcami i podważyła tym samym zaufanie do budżetu obywatelskiego ${ }^{20}$.

15 Kalisiak-Mędelska (2016): 359.

16 Glejt, Uziębło (2018): 393-396.

17 Art. 233 i 239 ustawy z 27 sierpnia 2009 r. o finansach publicznych, Dz. U. 2009, Nr 157, poz. 1240 .

18 Radziszewski (2016): 49-60.

19 Antoń-Jucha (2014).

20 Skomra (2014). 


\section{Dylematy ekonomiczne}

Dylematy ekonomiczne mają szeroki zakres, stąd autorka podzieliła je na trzy rodzaje:

- dylematy finansowe, skupiające się na wymiarze wielkości puli środków przeznaczonych na budżet obywatelski;

- dylematy zwiąane z ekonomicznym wymiarem wydatkowania środków publicznych, a więc ich alokacja;

- dylematy wynikające z konieczności i chęci realizowania celów zrównoważonego rozwoju przez władze miast.

\subsection{Dylematy finansowe}

Wysokość środków finansowych na realizację budżetów obywatelskich określa corocznie rada miasta. Celem budżetu obywatelskiego jest włączenie mieszkańców w proces planowania wydatków budżetowych. Z drugiej strony dzięki zgłaszanym i realizowanym projektom władze lepiej poznaja potrzeby obywateli w zakresie wydatkowania środków publicznych.

Jednym z dylematów, jaki jest wskazywany w kontekście budżetu obywatelskiego, jest jego wymiar finansowy. W znaczącej większości przypadków wysokość budżetu partycypacyjnego jest na poziomie ok. 1-2\% całego budżetu samorządu. Miasta na prawach powiatu mogą określić poziom budżetu obywatelskiego minimalnie w wysokości 0,5\%. Próg ten nie jest zbyt wygórowany, jeśli nie nazwać go niskim. Zakłada on jednak, że może on być znaczenie wyższy to decyzja władz lokalnych. Taki zapis minimalnej wartości budżetu reguluje wspomniana powyżej u.z.u.o. Zdarza się jednak, że poziom ten jest wyższy i sięga nawet $4 \%$ budżetu. Finansiści wskazuja, że poziom $1 \%$, a nawet $4 \%$ całego budżetu jest kroplą w morzu. Ich zdaniem nie ma on znaczacego wpływu na kierunek dokonywanych wydatków. Zdaniem finansistów nie można wskazać wpływu efektywności budżetu obywatelskiego na efektywność całego budżetu. Jednakże znaczenie budżetu obywatelskiego nie ma charakteru przede wszystkim finansowego, a społeczno-edukacyjny. Mieszkańcy uczą się podejmować świadome decyzje społeczne i przyjmować demokratyczne postawy.

Można zatem zauważyć duże różnice w wysokości kwot przeznaczonych do wykorzystania w ramach budżetu obywatelskiego. Nie określono, jaka pula środków powinna być przeznaczona na budżet obywatelski, tak aby był najbardziej efektywny. Nie można też powiedzieć, czy taki budżet jest porównywalny względem zakresu zadań, do których realizacji jest zobowiązany samorząd. Przykładem może być budżet Łodzi, w którym w 2013 r., zakontraktowano $20 \mathrm{mln}$ złotych do rozdzielania przez mieszkańców. W tym samym roku w Poznaniu czy Białymstoku w ręce obywateli oddano tylko ok. 10 mln złotych. Wielkość dostępnej puli środków oczywiście w znacznym stopniu zależy od wielkości miasta i wielkości jego budżetu. Im większe miasto i większy jego budżet, tym większy będzie budżet obywatelski. Zasada ta jednak nie zawsze się sprawdza. W Szczecinie w 2014 r. na ten cel przeznaczono 5 mln złotych, co 
w stosunku choćby do wspomnianego Białegostoku jest znacznie skromniejszą kwotą w porównaniu z wielkością miasta.

Jeszcze większe różnice mogą być w znacznie mniejszych miastach. Wspomniany Kraśnik w 2013 r. przeznaczył na ten cel $2 \mathrm{mln}$, co stanowiło aż 2,5\% całego budżetu, a w tym samym roku wydane 20 mln złotych w Łodzi stanowiło jedynie $0,5 \%$ całego jej budżetu ${ }^{21}$. Niekoniecznie zatem duże miasta maja większy budżet obywatelski. Raczej należałoby powiedzieć, że mieszkańcy w sposób zamierzony dążą do zwiększenia swojego udziału i chęci współpracy z władzami. To rozwarstwienie zależy też od świadomości władz miasta i ich chęci do współzarządzania miastem $\mathrm{z}$ jego obywatelami.

Czynniki finansowe wpływające na skuteczność wydawanych środków w ramach budżetu obywatelskiego są związane z faktem, że na zadania wybierane przez mieszkańców przeznacza się zazwyczaj ściśle określoną kwotę. Bardzo ważna jest więc poprawność określenia wysokości środków finansowych niezbędnych do wykonania poszczególnych zadań. W praktyce często koszty zadań są niedoszacowane. Powoduje to, że wobec ograniczoności środków budżetowych dane zadanie nie jest wykonywane lub jest wykonywane w niepełnym zakresie.

\subsection{Dylematy wynikające $\mathrm{z}$ alokacji środków}

Alokacją środków budżetu obywatelskiego nazwać można wskazanie rodzajów zadań, które powinny być finansowane w ramach tego budżetu. Nie ma wątpliwości, że środki te są środkami budżetu danej jednostki samorządowej, a więc np. miasta. Środki te muszą być wydatkowane na zadania, które mieszczą się w katalogu ustawowych zadań własnych danego samorządu terytorialnego ${ }^{22}$. W praktyce więc zakres alokacji środków budżetu obywatelskiego jest ograniczony do zadań własnych samorządu (np. miasta). Nie ma możliwości finansowania w ramach budżetu obywatelskiego zadań zleconych, które są realizowane na podstawie porozumień. Sa to bowiem zadania obce i co do zasady - powinny być finansowane ze środków podmiotu zlecającego lub powierzającego dane zadanie.

Zadania własne samorządu można dzielić się na zadania obligatoryjne i fakultatywne. Dylematem jest więc kwestia, czy w ramach budżetu partycypacyjnego moga być finansowane zadania obligatoryjne czy fakultatywne. Ustawodawca nałożył obowiązek wykonywania przez jednostki samorządu terytorialnego zadań obligatoryjnych. Takie ograniczenie wynika z konieczności zaspokojenia potrzeb mieszkańców na przynajmniej minimalnym poziomie. Jednostki samorządowe muszą zapewnić w swoim budżecie środki na pokrycie wydatków z nimi związanych i nie mogą uchylać się od ich realizacjii² Wynika to z tego, że zadania obligatoryjne mają sztywny ustawowy charakter

\footnotetext{
21 Niklewicz (2014): 102.

22 Ruśkowski, Salachna (2010): 660.

${ }^{23}$ Kańduła, Przybylska (2008): 15.
} 
i jednostka nie może ich dowolnie kształtować ${ }^{24}$. Szczególne miejsce w katalogu tych zadań zajmuja zadania podlegające działalności regulacyjnej państwa, takie jak: oświata, służba zdrowia i pomoc społeczna ${ }^{25}$.

Wyciagając z tego wnioski, należałoby jasno określić, że zadania obligatoryjne powinny być realizowane przez władze samorządowe w ramach budżetu podstawowego. Środki z budżetu obywatelskiego moga być przeznaczane na zadania obligatoryjne, ale tylko w zakresie wykraczajacym poza minimalny poziom zaspokajania potrzeb obywateli. Pojawia się pytanie, jak można określić poziom minimum. Czy mieszkańcy moga zgłaszać w ramach projektów budżetu obywatelskiego takie, których celem jest realizacja potrzeb podstawowych? W 2016 r. w Poznaniu mieszkańcy w ramach budżetu obywatelskiego zgłosili projekt mający na celu umycie kloszy latarń miejskich. Projekt został odrzucony jako zadanie, które powinno być zadaniem podstawowym władz miasta. Czy takie zadanie powinno być odrzucone i finansowane w ramach „właściwego" budżetu, czy też powinno być zakwalifikowane i rozliczone w ramach budżetu obywatelskiego? Kto powinien taką decyzję podjać: mieszkańcy czy władze miasta?

Z drugiej strony należałoby przyjrzeć się alokacji środków w zadania fakultatywne, które podejmuje samorząd w zależności od potrzeb występujących na jego terenie i swoich możliwości finansowych ${ }^{26}$. Władze samorządowe powinny więc mieć samodzielność w zakresie zadań fakultatywnych, zarówno co do ich rodzaju, jak i sposobu wykonania. Tymczasem w praktyce samorządowej takiej samodzielności nie ma. W świetle rozstrzygnięć nadzorczych i orzecznictwa sądowego zadania fakultatywne mogą być bowiem wykonywane tylko wtedy, kiedy istnieje do tego wyraźna podstawa prawna ${ }^{27}$. W odniesieniu do budżetu obywatelskiego należy więc zwrócić szczególną uwagę na to, czy zadania wyłonione przez mieszkańców maja taką podstawę. Nie zawsze potrzeby społeczne wpisują się bowiem w zadania danej jednostki samorządowej. Watpliwości może budzić chociażby wyłonienie do realizacji w ramach PBO 2016 np. zadania „Winnice Poznania”. Założeniem pomysłodawców było obsadzenie winoroślami nadbrzeży Warty na odcinku $1 \mathrm{~km}$ i utworzenie w ten sposób ogrodu społecznego (,przez mieszkańców i dla mieszkańców”), z którego plonów mieszkańcy mogliby korzystać za darmo. Powstaje pytanie: czy takie przedsięwzięcie ma podstawę w ustawodawstwie dotyczącym zadań gminy lub powiatu?

Należy też zwrócić uwagę, że zadania samorządu terytorialnego dzielą się na zadania projektowe i procesowe. Zadania projektowe mają jasno określony przedział czasowy i charakter tymczasowy. Zadania procesowe maja charakter ciagły i dlatego trudno jest jednoznacznie określić datę początkową i końcowa. Czasem zadanie projektowe rodzi zadanie ciagłe. Przykładem mogłoby być zbudowanie przedszkola w ramach projektu, ale długofalowe utrzymywanie

\footnotetext{
${ }^{24}$ Czarnecki (2014): 127-131.

25 Denek (2001): 7-27.

26 Sochacka-Krysiak (2008): 116.

27 Jastrzębska (2011): 35-42.
} 
go byłoby zadaniem procesowym. Wydaje się, że w ramach budżetu obywatelskiego powinny być proponowane i wybierane zadania projektowe, gdyż zakres finansowania dotyczy jedynie jednorazowego wkładu, a nie długofalowego finansowania. Zadania te powinny również zmieścić się w budżecie na dany rok $^{28}$. Wspomniana powyżej inwestycja „Winnice Poznania” miała charakter projektowy, ale jej efekty, czyli uprawa wieloletnia, rodziły charakter procesowy. Inwestycja nie została zrealizowana, gdyż prace zostały wstrzymane przez prezydent Poznania. Inicjatorzy pomysłu sprawę skierowali do sądu. Decyzja o wstrzymaniu budowy winnic argumentowana była właśnie m.in. koniecznością ciagłego dofinansowywania projektu i braku uwarunkowań klimatycznych dla tego typu inwestycji.

Zatem w przypadku budżetu obywatelskiego skuteczność alokacji środków może być rozpatrywana jako stopień realizacji wyłonionych zadań. Najwyższy poziom skuteczności zostanie osiagnięty, jeśli wszystkie zadania wybrane w ramach budżetu obywatelskiego zostaną wykonane w określonym czasie. To, jakie projekty zostana zaakceptowane na etapie zgłaszania projektów i dopuszczone do głosowania, wydaje się istotne i nie budzi kontrowersji.

\subsection{Partycypacja obywatelska jako dylemat zrównoważonego rozwoju}

Jeden z 17 Celów Zrównoważonego Rozwoju (nr 11) określony w Agendzie 2030 ONZ odnosi się do budowy bezpiecznych, sprzyjających włączeniu społecznemu oraz zrównoważonych miast i osiedli ludzkich. Cele 11.3, 11.4, 11.7 podkreślaja rolę partycypacji obywatelskiej jako celu samego w sobie, ale też w tej partycypacji upatrują współodpowiedzialności mieszkańców za realizację celu $11^{29}$. Zadania te, które wymagaja włączenia się mieszkańców w procesy zarządzania miastem, rodzą więcej dylematów. Zrównoważony rozwój na poziomie miast realizowany jest przede wszystkim przez samorządy. Wskazują one narzędzia i metody realizowania celów zrównoważonego rozwoju w strategii i polityce rozwoju miasta. Strategia ta jest wypadkową wytycznych narzuconych przez organy państwowe, ale powinna uwzględniać również oczekiwania i potrzeby samych mieszkańców. Zakłada więc szeroko rozumianą partycypację obywatelska.

Zrównoważony rozwój koncentruje się na trzech obszarach: gospodarce, środowisku i życiu społecznym. Analiza zakresu zgłaszanych i wybieranych projektów w ramach budżetu obywatelskiego wskazuje, że dominuje w nich tendencja realizowania potrzeb środowiskowych i społecznych mieszkańców. Rodzi się pytanie, czy budżet powinien (czy musi) wpasowywać się w dążenie do zrównoważonego rozwoju. Mieszkańcy zgłaszają i wybierają projekty, które odzwierciedlają ich wewnętrzne potrzeby. Autentyczność tych potrzeb jest spójna z zrównoważonym rozwojem, w którego centrum znajduje się człowiek.

\footnotetext{
28 Gońda (2017): 173-175.

29 ONZ (2015).
} 


\section{Dylematy organizacyjne}

W ramach dylematów organizacyjnych jako pierwszy wskazać można sposób organizacji procesu wyłaniania zwycięskich projektów. Nierzadko zdarza się, że mieszkańcy zgłaszają projekty trudne, albo wręcz niemożliwe do zrealizowania. Trudności, jakie występuja, mogą wynikać z unormowań prawnych związanych z nieruchomością czy nieodpowiednich uwarunkowań (np. klimatycznych jak w przypadku „Winnic Poznania”.

Organizacja samych wyborów jest też nie lada wyzwaniem. Oznacza to, że budżet gminy powinien być uchwalany z większym wyprzedzeniem, niż gdyby nie uwzględniano budżetu obywatelskiego (czyli w sposób tradycyjny) ${ }^{30}$. Nie tylko musi być brany pod uwagę czas na podjęcie decyzji przez radę miasta, ale czas na zgłoszenie, głosowanie i wybór projektów budżetów obywatelskich. To narzuca dopasowanie dyscypliny finansów publicznych i harmonogramu prac nad budżetem miasta. Wymusza wyznaczenie zupełnie innych ram czasowych na poszczególne fazy ustalania budżetu miasta. Spotyka się to wielokroć z niechęcią ze strony samorządu.

Wśród najczęściej dostrzeganych problemów wskazuje się, że proces współdecydowania nie jest efektywny - podnoszą to szczególnie władze miast, które uważaja, że taki proces wymaga poświęcenia (nie tylko od nich samych, ale i mieszkańców), więcej czasu, większych zasobów finansowych i organizacyjnych, tym samym nie gwarantuje osiagnięcia najlepszych wyników. To stanowisko zniechęca władze do korzystania z instrumentów partycypacji. Z perspektywy samorządowców stanowią one nadprogramowe obowiązki, których realizacja wydłuża procesy podejmowania decyzji oraz często wymaga poniesienia dodatkowych kosztów (np. zorganizowania spotkań konsultacyjnych z mieszkańcami czy warsztatów prowadzonych przez wykwalifikowanego moderatora). Nierzadko w związku z tym pojawia się pytanie, jak wybrać właściwych partnerów społecznych, tak aby reprezentowali rzetelnie stanowisko obywateli, i jak ich włączyć w proces prac nad podjęciem decyzji ${ }^{31}$. Ostatecznie, jak dobrać reprezentacje organizacji pozarządowych, w tym ruchów miejskich, aby nie powodowało to niepotrzebnych konfliktów? Czy to powinna być decyzja samej organizacji czy konsultowana z władzami miasta?

Władze miast zgłaszaja dodatkowo obawy związane z utratą wpływu na kształt budżetu. W końcu to mieszkańcy decydują o tym, który z proponowanych budżetów wybierają. Bywa czasem stosowana praktyka, że zamiast referendum, w którym wszyscy mieszkańcy dokonują wyboru, stosowane sa inne formy podejmowania decyzji w zakresie wyboru projektów. Jak stwierdza art. 5a ust. 4 ustawy o samorządzie gminnym: „w ramach budżetu obywatelskiego mieszkańcy w bezpośrednim głosowaniu decydują corocznie o części wydatków budżetu gminy"32. Ustawodawca nie określa jednak, jak ma zostać zorganizowane bezpośrednie głosowanie i w jakiej formie. Do tej pory samo-

${ }^{30}$ Sorychta-Wojsczyk (2015): 421-430.

31 Poczykowska (2013): 52.

${ }^{32}$ Art. 5a ust. 4 ustawy z 8 marca 1990 r. o samorządzie gminnym, t.jedn.: Dz. U. 2019, poz. 506 . 
rządy czasem wskazywały komisję, która w imieniu mieszkańców dokonywała wspólnie wyboru. Takie rozwiązanie jest niezgodne z założeniami budżetu. Nawet jeśli gremium komisyjne reprezentuje stanowiska różnych grup interesów, to nie są one głosem całego społeczeństwa. Różne formy przeprowadzania bezpośrednich wyborów budzą podejrzenia braku transparentności i ich rzetelności.

Nie zawsze raz wdrożony budżet obywatelski cieszy się sukcesem i bardziej aktywizuje społeczność. Czasem wprowadzane modyfikacje organizacyjne moga zaburzyć jego funkcjonowanie. Dobrym przykładem jest budżet obywatelski Puław. W drugiej edycji tego budżetu, a mianowicie w 2014 r., władze miasta dopuściły możliwość głosowania na projekty przez Internet. Celowość takiej zmiany była oczywista, podążanie za nowoczesnymi kanałami komunikacji, wykorzystywanie narzędzi e-administracji, a także chęć podwyższenia frekwencji. Wydawać by się mogło, że fakt, iż głosować mogą wszyscy, nie opuszczając domu, znaczenie podniesie frekwencję. Jednakże okazało się, że zwolennicy jednego z proponowanych projektów wykorzystali tę okoliczność, aby przeforsować swój projekt. Zbierali dane osobowe mieszkańców i podszywając się pod nich, głosowali na swój projekt. Nie tylko naruszyło to ochronę danych osobowych, ale mogło wpłynąc na sfałszowanie wyników wyborów. Ostatecznie unieważniono pierwsze głosowanie i przeprowadzono drugie, tradycyjne głosowanie. Taki problem pojawił się też w innych miastach (np. w Płocku). Obecnie coraz więcej miast zaczyna wykorzystywać głosowanie za pośrednictwem Internetu, ale wprowadza liczne obwarowania prawne i blokady uniemożliwiające fałszownie wyników.

Równie niejasny wydaje się sposób zgłaszania projektów przez grupy interesariuszy. Nie ma jednolitych zasad co do tego, jak ma wyglądać procedura zgłaszania projektów. W niektórych miastach takie pomysły zgłaszać moga wszyscy pełnoletni mieszkańcy, w innych - osoby nieletnie, a nawet dzieci. Dostęp powszechny, a więc dopuszczenie wszystkich bez ograniczeń, zgodny jest z zasadą dostępności, a więc przeciwdziałania wykluczeniom. Rodzą się jednak pytania, czy na przykład dziesięciolatek wie, co dla mieszkańców będzie najlepsze. Czy jego pomysł potrafi sprostać oczekiwaniom innych? Do tej pory nie ma jednoznacznych regulacji prawnych w kwestii zgłaszania projektów, a ta decyzja zostaje w rękach samorządu. Ciekawym przypadkiem jest Gorzów Wielkopolski, gdzie powołano Radę Działalności Pożytku Publicznego, która między innymi rokrocznie organizuje wraz z władzami miasta konsultacje społeczne związane z budżetem obywatelskim. Celem tych konsultacji jest dopracowanie regulaminów, zasad i zakresu budżetu obywatelskiego ${ }^{33}$.

Dylematem organizacyjnym są też kwalifikacje zaangażowanych $\mathrm{w}$ tym zakresie pracowników samorządowych, a w zasadzie czasem ich brak. Nie zawsze osoby zajmujące się organizacją i wdrażaniem procesu mają wiedzę na temat celu, funkcjonowania i istoty budżetu obywatelskiego. Dość często zdarza się, szczególnie w mniejszych miejscowościach, że jednostki samorządu (np. przedstawiciele urzędu miasta) zajmujące się realizacją budżetu obywa-

\footnotetext{
${ }^{33}$ Tekst dostępny na: <http://www.gorzow.pl/pl/3333/Budzet_obywatelski>.
} 
telskiego nie są kompetentne ani nie potrafią udzielać kompletnych informacji interesariuszom budżetu. Mieszkańcy nie tylko nie mogą liczyć na wsparcie z ich strony, ale idea budżetu partycypacyjnego nie jest właściwie i efektywnie propagowana. Taka sytuacja może również naruszać zasadę dostępności. Niekoniecznie zatajanie, ale wystarczy nawet niezbyt intensywne promowanie budżetu daje szansę na wygraną tym, którzy zgłaszają projekty, gdyż może wpływać na zmniejszenie liczby konkurencyjnych projektów.

\section{Dylematy społeczne}

Dylematy społeczne można rozpatrywać w dwóch aspektach. Po pierwsze - ze względu na problemy ustrojowe, czy inaczej mówiąc: polityczne. Po drugie - z perspektywy obywatela, jego postaw społecznych i zainteresowania samym budżetem partycypacyjnym.

\subsection{Dylematy polityczne}

W Polsce obserwuje się kryzys systemu samorządowego, który przejawia się brakiem efektywności władz. Nie tylko chodzi tu o efektywność funkcjonowania organów administracji samorządowej, ale również brak silnego związku między władzami samorządowymi a obywatelami. Jak to trafnie określił Hausner, w Polsce można dostrzec „fasadowość” demokracji lokalnej ${ }^{34}$. Przejawia się ona brakiem znacznego wpływu obywateli na decyzje i współzarzadzanie dobrem lokalnym. Zdaniem Hausnera: „Polski porządek instytucjonalny nie sprzyja aktywności obywatelskiej i obecności obywateli w przestrzeni publicznej. Sa oni z niej wypierani i wycofali się do sfery prywatnej. A jeśli już pojawiaja się w przestrzeni publicznej, to jako klienci podmiotów władzy, reprezentanci indywidualnych lub korporacyjno-zawodowych interesów"35. Wcześniej też zauważano już niepokojące sygnały. „Można spotkać się z opinią że źródłem partycypacji jest sprzeciw wobec zbyt silnej hierarchii biurokratycznej i technokratycznej”36. Dialog społeczny jest w Polsce dość młoda metodą współpracy. Żadna ze stron - ani mieszkańcy, ani władze samorządowe - nie posiada dobrze opracowanych, skutecznych systemów komunikowania się. Wciąż jest to słaba przestrzeń relacji.

Zmiany, jakie powinny następować, muszą podążać od demokracji przedstawicielskiej w stronę demokracji deliberatywnej. Mieszkańcy odwracają się od samorządów, gdyż nie widzą w nich swoich wiarygodnych reprezentantów. Upatrywanie w budżecie obywatelskim remedium na kryzys samorządności wydaje się dobrym pomysłem. Do takich samych wniosków doszli również badacze tematu nie tylko w Polsce, gdyż osłabienie udziału mieszkańców w życiu publicznym zauważalne jest również $\mathrm{w}$ innych krajach ${ }^{37}$. Budżet obywatelski

\footnotetext{
${ }^{34}$ Hauser (2013): 13.

${ }^{35}$ Hausner (2013): 14.

36 Skrzypiec, Długosz (2007): 7.

37 Baiochi, Ganuza (2014).
} 
w sposób faktyczny zwiększa aktywność mieszkańców i ich partycypację we współpodejmowanie decyzji budżetowych. Budżet ten przywraca mieszkańcom tzw. prawo do miasta.

Budżet obywatelski zbiera informacje od mieszkańców o ich jawnych i ukrytych potrzebach społecznych. Dzięki temu podtrzymuje procesy decentralizacji władzy. Prowadzi to również do podwyższenia zaufania mieszkańców do siebie nawzajem, a tym samym integruje społeczność lokalna. Obywatele najlepiej wiedza, co i kto wymaga wsparcia, pomocy, kontroli ze strony władz miasta, jakie inwestycje są konieczne, aby podwyższyć jakość ich życia. Czasem są to drobne sprawy, których nikt z władz nie brał pod uwagę, a ich realizacja może zmienić wiele - może to być np. podjazd dla osób niepełnosprawnych między chodnikiem a ulica. Czasem te zadania nie kwalifikują się do realizacji w ramach samego budżetu obywatelskiego, ale wskazują oddolne potrzeby. To też jest wartością samą w sobie ${ }^{38}$.

\subsection{Dylematy obywatelskie}

Realizacja budżetów partycypacyjnych ma silny walor edukacyjny. W budowaniu społeczeństwa obywatelskiego budżet obywatelski może wpływać na kształtowanie demokratycznych postaw. Obywatele bowiem dzięki zebranym przy nim doświadczeniom nie tylko moga, ale i chcą uczestniczyć w życiu społeczności lokalnych. Jeśli weźmiemy pod uwagę dzieci, które współuczestnicza w procesie dzięki zaangażowaniu rodziców, czy młodzież, która sama może zgłaszać projekty, budżet partycypacyjny kształtuje świadomość przyszłych wyborców.

Idea partycypacji mieszkańców zakłada, że sa oni otwarci na współpracę i chętnie angażuja się we wszelkie inicjatywy. Wykorzystują do tego swoje kompetencje. W praktyce poziom aktywności mieszkańców nie jest zbyt wysoki. Większość Polaków deklaruje, że jest zainteresowana tym, jakie działania podejmuje władza samorządowa, w praktyce ok. $30 \%$ tylko dokładnie wie, jakie inwestycje w ich lokalnym środowisku są podejmowane, co więcej, jeszcze mniejsza część aktywnie bierze udział $\mathrm{w}$ procesach podejmowania tych decyzji. Okazuje się, że jeśli projekt czy inwestycja są bardzo czasochłonne, chęć partycypacji mieszkańców jest coraz mniejsza. Blisko 1/4 Polaków poszukuje informacji o tym, jakie decyzje sa podejmowane przez władze gmin, w których mieszkaja. Tylko 1/10 obywateli jest skłonna brać udział w konsultacjach, a znikomy procent (poziom 2,5\%) wykazuje się aktywną partycypacją i włącza się w procesy współdecydowania ${ }^{39}$. W rzeczywistości okazuje się, że niski poziom aktywności obywateli nie wynika z braku chęci i lenistwa mieszkańców, a jedynie z braku odpowiedniej wiedzy o możliwościach partycypowania w podejmowaniu kluczowych decyzji. Przyczyną takiego stanu rzeczy może też być niechęć władz samorządowych do dzielenia się tą wiedzą z mieszkańcami.

\footnotetext{
38 Niklewicz (2014): 104.

39 Hausner (2013): 12.
} 
Dodatkowo obywatele chętniej włączają się w działania w obszarach, które dotyczą ich bezpośrednio. Co więcej, projekty i generowanie dla nich rozwiązań, które nie wydają się nadmiernie czasochłonne, spotykają się z większym entuzjazmem i zaangażowaniem mieszkańców.

Budżet obywatelski podkreśla podmiotowość obywatela jako „aktora kształtującego te aspekty rzeczywistości, które go dotycza, pozwala na podjęcie działań oraz wzięcie za nie odpowiedzialności. Edukacja obywatelska poprzez stwarzanie warunków i zachęcanie do postaw obywatelskich może być receptą na niską aktywność społeczną Polaków" ${ }^{40}$. Co więcej - władze miast dostają informację o potrzebach mieszkańców, które mogą brać pod uwagę, kreujac nowe plany i strategie rozwoju miasta.

Poważnym problemem związanym z budżetem obywatelskim jest podejmowanie takich działań, które spowoduja, że aktywność obywateli nie będzie miała charakteru powierzchownego. W takich okolicznościach budżet partycypacyjny służy jedynie legitymizacji projektów, których inicjatorami sa władze lokalne, forsujace swoje pomysły. Takie symboliczne realizowanie partycypacji nie wypełnia kryterium rzeczywistego zaangażowania mieszkańców. Zjawisko to obserwuje się nie tylko w państwach demokratycznych, ale i autorytarnych ${ }^{41}$.

Niejednokrotnie można zauważyć podważanie kompetencji mieszkańców w zakresie dyskutowanych problemów miejskich. Złożone problemy społeczne wymagają eksperckiej wiedzy, którą część mieszkańców nie dysponuje. Organy administracji samorządowej mają niezbędne zasoby, które moga wykorzystać w procesach planowania i realizowania rozwiązań tych złożonych problemów. Taka argumentacja nie pojawia się w przypadkach decyzji, które dotyczą bezpośrednio mieszkańców (np. nieuwzględnienie opinii mieszkańców budowy spalarni śmieci czy składowiska odpadów powoduje konflikt). Konsekwencją może być zaniechanie, przesunięcie w czasie, czy wręcz rezygnacja z inwestycji. Argument za niewłączaniem obywateli z proces opracowywania dokumentów strategicznych z uwagi na brak ich wiedzy eksperckiej jest niestosowny. Zważywszy na cele zrównoważonego rozwoju, ten sposób myślenia jest wyraźnie błędny. Celem przecież jest właśnie możliwość udziału mieszkańców w zintegrowanym i zrównoważonym planowaniu, myślenie dyskredytujące wiedzę obywateli jest jednak dość powszechne.

Kolejne wątpliwości wiążą się z przekonaniem, że zaangażowanie poszczególnych grup interesów może wywoływać konflikty. W procesach partycypacji biora udział rywalizujace ze sobą grupy interesu, a z uwagi na ograniczone zasoby należy szukać zadowalającego wszystkich kompromisu. Ograniczony poziom środków finansowych przeznaczonych na realizację programu wymusza ograniczenie wielu obszarów interwencji. Prowadzić to może do protestu środowisk, które wykluczone, ograniczają niejednokrotnie swoją aktywność. Problem ten skupia się nie tylko w obszarze finansów. Może to również do-

40 Poczykowska (2013): 54.

41 Sintomer et al. (2014): 17. 
tyczyć sporów o prawo do określonej przestrzeni, gdzie różne grupy zgłaszaja różne pomysły na przykład na rewitalizację czy zagospodarowanie przestrzenne danego terenu.

\section{ZAKOŃCZENIE}

Budżet obywatelski jako lekarstwo na kryzys samorządności i demokracji w Polsce rodzi wiele dylematów Mieszkańcy stają się coraz bardziej świadomi swoich praw i obowiązków. Co więcej, coraz mocniej podkreślają swoje potrzeby w ramach włączania się w procesy partycypacyjne. Świadomość partycypacji i demokracji wspierana powinna być przez władze samorządowe. Wydaje się, że wspólne działania władz miast i mieszkańców powinny mieć na celu optymalizację jakości życia w mieście.

Dylematy, z jakimi się boryka budżet obywatelski, maja różne źródła. Niejednokrotnie się przenikają: wątpliwości, które wyjściowo można określić prawnymi czy finansowymi, mają na przykład skutki społeczne. Dużą część pojawiających dylematów stanowią ograniczenia prawne, brak regulacji prawnych albo niewłaściwie ich sformułowanie, co powoduje różnorodność interpretacji. Uregulowania w tym zakresie nie mogą być zbyt sztywne, gdyż partycypacja z założenia jest dobrowolna i nie można obywateli do niej zmuszać. To powinna być aktywność oddolna, a nie działalność obligatoryjna, w przeciwnym razie nie będzie się silnie rozwijać. Ludzie bowiem aktywizują się, jeśli tego chca, a nie dlatego, że ktoś ich do tego zmusza. Zapisy prawne powinny regulować funkcjonowanie budżetu, aby jego organizacja nie była dowolnie interpretowana przez samorząd.

Równie istotne są dylematy finansowe związane są z wielkością budżetu. Jaką część budżetu właściwego stanowi budżet obywatelski, decydują władze samorządowe. Im efektywność i skuteczność alokacji środków publicznych i aktywność mieszkańców większa, tym władze chętniej zwiększają pulę środków przeznaczanych na ten cel.

Organizacyjne dylematy wynikają z tego, że budżet jest stosunkowo młodym instrumentem. Władze samorządowe i mieszkańcy uczą się, często drogą prób i błędów, jakie rozwiązania i sposób organizacji będą najskuteczniejsze. Co więcej - rzeczywistość ulega przekształceniom, więc i proces partycypacji mieszkańców się zmienia. Upraszczanie procesów decyzyjnych, wprowadzanie dobrych rozwiązań technologicznych jest nieuniknione, choć wymaga to opracowania szczegółowych procedur.

Ostatecznie dylematy o charakterze społecznym są kwintesencją budżetu obywatelskiego. Jest on społecznym instrumentem majacym na celu jak największy wzrost partycypacji mieszkańców. Aspekt polityczny, edukacyjny czy demokratyczny są wyjątkowo ważne z perspektywy budowania społeczeństwa obywatelskiego.

Czy problemy, jakie wynikają z realizowania budżetu obywatelskiego można rozwiązać? Na pewno uregulowanie funkcjonowania jest wskazane. Nie ma jednak złotego środka, dzięki któremu budżet obywatelski mógłby sprawnie 
działać. W różnych miastach przybiera nieco inną postać. Na świecie różnice $\mathrm{w}$ formach realizacji budżetu obywatelskiego sa jeszcze większe. Każda społeczność lokalna jest nieco inna, ma różne tradycje, uwarunkowania historyczne, wręcz charakter - to wszystko wpływa na oczekiwania i potrzeby jej mieszkańców. Inne są intencje mieszkańców dużych miast, inne małych, inne miejscowości przemysłowych, a inne gmin nastawionych na rozwój turystyki. Nie można odgórnie wprowadzić zatem ograniczeń takich samych dla wszystkich, gdyż jest to indywidualna kwestia. Wydaje się, że dobrym sposobem na rozstrzyganie dylematów są dyskusja i dialog, podczas których mieszkańcy z władzami lokalnymi wspólnie ustalaja, jak budżet obywatelski ma wygladać. Wzajemne zaufanie i chęć współpracy są warunkiem rozwoju partycypacji mieszkańców w procesie współzarządzania miastem.

\section{Maja Btaszak}

Wyższa Szkoła Bankowa w Poznaniu

maja.blaszak@wsb.poznan.pl

https://orcid.org/0000-0003-2108-0954

Antoń-Jucha, A. (2014). Budżet obywatelski w Kraśniku: 1130 osób wybrało dach na kościele. Dziennik Wschodni z 14 marca 2014.

Baiochi, G., Ganuza, E. (2014). Participatory budgeting if emancipation mattered. Politics and Society 42(1): $3-5$.

Boryczka, E.M. (2015). Partycypacyjne instrumenty zarządzania jednostkami samorządu terytorialnego, [w:] A. Nowakowska (red.), Nowoczesne metody i narzędzia zarządzania rozwojem lokalnym i regionalnym. Łódź: 42-43.

Bułajewski, S. (2013). Demokracja bezpośrednia w jednostkach samorządu terytorialnego w Polsce - stan obecny i perspektywy zmian, [w:] W. Skrzydło, W. Szapował, K. Eckhardt, P. Steciuk (red.), Konstytucyjne podstawy budowania i rozwoju społeczeństwa obywatelskiego w Polsce i na Ukrainie - dobre praktyki. Rzeszów-Przemyśl: 92-108.

Czarnecki, K. (2014). Udział mieszkańców w ustalaniu wydatków budżetu gminy w ramach tzw. budżetu partycypacyjnego (na przykładzie Torunia w latach 2013-2014). Prawo Budżetowe Państwa i Samorządu 2: 125-145.

Denek, E. (2001). Płaszczyzny rozpatrywania samodzielności samorządu terytorialnego. Zeszyty Naukowe Akademii Ekonomicznej w Poznaniu 7: 7-27.

Glejt, P. (2015). Budżet obywatelski w wyznaczaniu zadań publicznych, [w:] G. Szpor, B. Szmulik (red.), Jawność i jej ograniczenia. Tom 9: Zadania i kompetencje. Warszawa: 375-383.

Glejt, P., Uziębło, P. (2018). Kilka uwag o „nowych” instrumentach partycypacji mieszkańców na poziomie samorządowym. Wrocław: 393-403.

Gońda, E. (2017). Tak zwany budżet obywatelski jako instrument alokacji środków publicznych w jednostkach samorządu terytorialnego, [w:] Relacje fiskalne państwo-samorząd terytorialny. Prace Naukowe Uniwersytetu Ekonomicznego we Wrocławiu. Wrocław: 169-177.

Hausner, J. (2013). Narastające dysfunkcje, zasadnicze dylematy, konieczne działania. Raport o stanie samorządności terytorialnej w Polsce. Kraków.

Jastrzębska, M. (2011). Fakultatywne zadania własne gminy w świetle obowiązujących regulacji prawnych. Finanse Komunalne 1/2: 35-42.

Kalisiak-Mędelska, M. (2016). Budżet partycypacyjny - rzeczywisty czy pozorny instrument partycypacji społecznej? Przykład Łodzi, [w:] R.P. Krawczyk, A. Borowicz (red.), Aktualne problemy samorządu terytorialnego po 25 latach jego istnienia. Łódź: 353-374.

Kańduła, S., Przybylska, J. (2008). Organizacja działalności gospodarczej samorządu terytorialnego w Polsce. Poznań.

Kębłowski, W. (2013). Budżet partycypacyjny. Krótka instrukcja obsługi. Warszawa.

Kębłowski, W. (2014). Budżet partycypacyjny. Ewaluacja. Warszawa. 
Niklewicz, K. (2014). Budżety obywatelskie w kontekście wyborów samorządowych: szansa czy ryzyko? Kwartalnik Naukowy OAP UW „e-Politicon”: 99-119.

Peterson, M. (2010). An Introduction to Decision Theory. Cambridge: Cambridge University Press.

Poczykowska, K. (2013). Rola i znaczenie partycypacji publicznej, [w:] A. Maszkowska, K. Sztop-Rutkowska, Partycypacja obywatelska - decyzje bliższe ludziom. Białystok: 48-57.

Ruśkowski, E., Salachna, J. (red.) (2010). Nowa ustawa o finansach publicznych wraz z ustawa wprowadzającą. Komentarz praktyczny. Gdańsk.

Radziszewski, M. (2016). Wybrane instrumenty wykorzystywane w procesie budowy społeczeństwa obywatelskiego. Samorząd Terytorialny 26(6): 49-60.

Rytel-Warzocha, A. (2013). Budżet obywatelski. Disputatio 15: 65-77.

Sintomer,Y., Herzberg, C., Röcke, A., Allegretti, G. (2014). Transnational models of citizen participation: the case of participatory budgeting. Journal of Public Deliberation 8(2): Article 9. $<$ https://www.publicdeliberation.net/jpd/vol8/iss2/art9>.

Skomra, S. (2014). Kraśnik idzie na wojnę o dach kościoła. Gazeta Wyborcza Lublin z 25 kwietnia 2014.

Skrzypiec, R., Długosz, D. (2007). Budżet gminy bez tajemnic. Warszawa.

Sochacka-Krysiak, H. (red.) (2008). Gospodarka finansowa jednostek samorządu terytorialnego w warunkach decentralizacji zarządzania sektorem publicznym. Warszawa.

Sorychta-Wojsczyk, B. (2015). Uwarunkowania wykorzystania budżetu obywatelskiego w administracji publicznej w Polsce. Zeszyty Naukowe Politechniki Ślaskiej. Seria Organizacja i Zarządzania 78: 421-430.

Swianiewicz, P., Klimska, U., Mielczarek, A. (2004). Nierówne koalicje - liderzy miejscy w poszukiwaniu nowego modelu zarządzania rozwojem. Warszawa.

\section{PARTICIPATORY BUDGETING IN POLAND AND ITS DILEMMAS}

\section{Sum mary}

The article presents the problem of participatory budgeting in Poland, as a popular form of cooperation between the administration and citizens. The study describes the influence of participatory budgeting on people's awareness and commitment to local issues. The author considers the legal, organizational, economic and social results of putting the procedure of participatory budgeting into practice. The aim of this article is to present the concepts of civic participation. The author describes the model of a participatory budget and the process of its evaluation.

Keywords: civic participation; participatory budgeting; local government budget; local finance; local development; civil society; city management; sustainable development 